\title{
REVIEW TEORETIK PEMEROLEHAN BAHASA DAN BAKAT BAHASA BAGI ANAK
}

\author{
Nurul Lailatul Khusniyah ${ }^{1}$
}

\begin{abstract}
ABSTRAK Pemerolehan bahasa menjadi kajian menarik tentang cara orang memperoleh bahasa pertama ataupun bahasa kedua. Individu memperoleh kecakapan bahasa bukan karena kelahirannya semata melainkan karena perkembangan dan pengalaman hidupnya. Tujuan utama dari penelitian ini adalah untuk mengetahui lebih mendalam tentang konsep teori keterkaitan pemerolehan bahasa dan bakat bahasa. Kajian dalam penelitian ini difokuskan pada kontroversi antara nurture dan nature. Teori ini menggambarkan pemerolehan bahasa yang diperoleh secara alami dan proses pembentukan. Bakat bahasa memiliki fase yang berbeda dalam proses pemerolehan bahasa.
\end{abstract}

\section{Keywords: Bakat, Bahasa, Pemerolehan.}

\section{Pendahuluan}

Bahasa memiliki peran yang sangat penting dalam kehidupan masyarakat. Dengan perkataan lain, sosok bahasa memiliki salah satu peran dan fungsi yang sangat mendasar yakni sebagai penyampai pikiran, gagasan, ide, maupun keinginan tertentu. Disiplin ilmu yang mengkaji bahasa sebagai objek formalnya adalah linguistik dan psikologi.Kedua disiplin ilmu itu sama-sama mengkaji mengenai bahasa, namun perbedaannya adalah terletak dari sudut pandang kajiannya yakni psikologi mengkaji bahasa dari sudut perilaku berbahasa, sedangkan linguistik mengkaji dari sudut struktur bahasa. Dengan demikian, linguistik memberikan kontribusi dalam bentuk pemikiran yang berkaitan dengan bahasa dan penggunaannya dan psikologi memberikan kontribusi dalam bentuk pemikiran yang berkaitan dengan proses mental yang terjadi ketika seseorang menggunakan bahasa. Kontribusi kedua ilmu di atas didasari dari pendapat Wilhelm Wundt yang menyatakan bahwa bahasa dapat dijelaskan dengan dasar prinsip-prinsip psikologis. ${ }^{2}$

Kita memiliki otak dan di dalam otak kita terdapat bahasa. Akan tetapi bagaimana bahasa itu diperoleh? Bagaimana kita menghasilkan dan memahami suatu pembicaraan? Pada saat dilahirkan kita tidak dapat berbicara, apalagi memahami suatu pembicaraan. Namun, saat berumur 4 tahun kita telah mempelajari kosakata, sintaksis, dan pelafalan. Hal ini mungkin terjadi pada anak di seluruh dunia, dalam bahasa apapun mereka. Pemerolehan bahasa merupakan proses penguasaan bahasa yang dilakukan oleh anak secara natural pada waktu anak belajar bahasa ibunya (native language). Istilah pemerolehan bahasa dipakai untuk padanan istilah dalam bahasa Inggris yakni acquisition.

Bidang penelitian pemerolehan bahasa sangat bervariasi, dan variasi pendekatan serta persfektif pemerolehan bahasa merupakan salah satu fenomena

1 Penulis merupakan dosen pada Fakultas Ekonomi dan Bisnis Islam UIN Mataram, email nurullaila@uinmataram.ac.id

2 Soenjono Dardjowidjojo, Psikolingistik: Pengantar Pemahaman Bahasa Manusia (Jakarta: Yayasan Obor Indonesia, 2005), h. 2. 
pertama yang diteliti dan berlanjut pada penelitian pemerolehan bahasa kedua. Guru, psikolog, ahli bahasa, praktisi pendidikan dan semua orang yang berada pada tingkat yang berbeda tertarik pada bidang kajian ini. Pandangan yang diadopsi pada bidang kajian tersebut adalah teori generative dan lebih tepatnya adalah kerangka government-Binding. ${ }^{3}$

Individu memperoleh kecakapan tertentu bukan karena kelahirannya semata melainkan karena perkembangan dan pengalaman hidupnya. Memang ia dianugrahi oleh Tuhan berupa potensi dasar dan kapasitas yang berbeda-beda untuk berperilaku inteligen. Dari kedua kalimat ini tentunya sudah jelas bahwa kecakapan itu dapat dibedakan menjadi dua hal, yaitu kecakapan nyata dan kecakapan potensial.

Kecakapan nyata merupakan kecakapan yang didapat dari kenyataan hidup, baik dari pengalaman hidup sendiri maupun dari mempelajari pengalaman hidup orang lain. Jadi kecakapan ini dapat diperoleh individu melalui belajar dan belajar. Hal ini dapat segera didemonstrasikan dan diuji yang berdasarkan sesuatu, cara, bahan, dan hal tertentu yang pernah dijalaninya. Kecakapan potensial adalah suatu kecakapan yang didapatkannya dari bawaan atau keturunan, yang mungkin bisa berupa kemampuan dasar umum (general intelligence) dan kemampuan dasar khusus dalam bidang tertentu (bakat, aptitudes).

Konsep bakat bahasa memiliki hubungan lebih luas dengan konsep kemampuan manusia, yang meliputi variasi kognitif berdasarkan pada perbedaan kemampuan pebelajar. ${ }^{4}$ Maka kita perlu merumuskan konsep dasar terlebih dahulu. Hal ini diperlukan karena istilah-istilah kemampuan (ability), bakat (aptitude), dan kecerdasan (intelegence) pada umumnya digunakan dalam penggunaan bahasa seharihari dan oleh karena itu, terlalu mudah untuk mencampur makna popular dengan definisi ilmiah. Istilah umum kemampuan mental biasanya digunakan dalam psikologi yang merujuk pada variasi sifat-sifat manusia yang melibatkan proses berpikir, penalaran, pengolahan informasi, dan pengetahuan baru. Dengan kata lain, kemampuan mental mencerminkan proses kognitif dan keterampilan. Ketika menggambarkan suatu proses dan keterampilan, para ahli ataupun bukan menggunakan istilah yang sama, kebanyakan menggunakan, kemampuan (ability), bakat (bakat), dan kecerdasan (intelligence). ${ }^{5}$

Meskipun beberapa cendekiawan membedakan antara istilah kemampuan dan bakat, namun dalam praktiknya digunakan secara sama. Selanjutnya, dalam konteks pendidikan seperti pembelajaran bahasa kedua, kemampuan (ability) sering digunakan merujuk pada kemampuan belajar (learning ability), yaitu potensi individu untuk memperoleh pengetahuan dan keterampilan baru. Sedangkan bakat bahasa bermakna sama dengan 'kemampuan bahasa (language ability)' dan biasanya

${ }^{3}$ Noam, Chomsky, Lectures on Government and Binding. (Dordrecht: Foris, 1981b)

${ }^{4}$ Zoltan Dornyei. The Psychology of the Language Learners Individual Differences in Second Language Acquisition. (New Jersey: Lawrence Erlbaum Associates, 2005), h.31

5Ibid, hlm.32 
dimaksudkan untuk menunjukkan 'kemampuan belajar bahasa (language learning ability)'. Bagaimana dengan istilah kecerdasan? Kecerdasan bukan sinonim dari kemampuan tetapi ketika itu bisa digunakan dengan sendiri-sendiri (yaitu bukan dalam frase 'kecerdasan spasial atau kecerdasan verbal'). Ini biasanya memiliki makna yang lebih luas, merujuk pada istilah bakat yang terbatas pada kinerja tetapi dalam waktu tertentu dapat dialihkan kedalam kinerja lain. 'Kecerdasan' secara kajian ilmiah bukan suatu kesatuan untuk membangun dan beberapa teori telah diusulkan pada masa lalu untuk menggambarkan tingkatan dari organisasi dalam identifikasi konstituen kemampuan. Pada tahun 1920-an, Spearman menjelaskan kecerdasan sebagai kombinasi faktor-faktor umum, yang dimiliki oleh setiap individu untuk tingkatan yang sama dalam tindakan intelektual, serta berbagai faktor-faktor tertentu yang bervariasi dalam kekuatan dari satu tindakan lain. Sepuluh satu kemudian Thurstone membedakan tujuh kemampuan mental utama; pemahaman verbal, kefasihan kata, fasilitas, visualisasi spasial, memori asosiasi, persepsi kecepatan, dan penalaran. Pada tahun 1960-an, struktur model kecerdasan terkenal dari Guilford terdiri dari struktur leborasi yang memiliki sebanyak 150 faktor-faktor yang berbeda. Pada waktu yang sama, pengaruh teori Cattell membagi kecerdasan umum menjadi fluid intelligence and crystallized intelligence. Fluid intelligence adalah kemampuan untuk beradaptasi dengan situasi baru, seperti yang dimanifestasikan dalam hasil tes kemampuan penalaran seperti bentuk-bentuk abstrak. Crystallized intelligence terdiri dari pengetahuan dan keterampilan yang diperoleh melalui pengalaman dan pendidikan.

Tentunya ada sejumlah perbedaan yang mendasar antara anak kecil yang belajar dari bahasa ibunya (native language), dengan orang dewasa yang belajar bahasa asing. Berdasarkan proses pemerolehan $\mathrm{B}_{1}$ dapat dipaparkan sebagai berikut, yaitu satu atau lebih bahasa yang secara natural diperoleh anak dalam lingkungan keluarga, tanpa melibatkan kegiatan aktif di kelas. Istilah $\mathrm{B}_{1}$ sering dikenal dengan mother tongue, yang diartikan sebagai bahasa ibu, bahasa setempat, bahasa daerah, dan bahasa nasional. Bahasa ibu adalah bahasa pertama yang dikenal oleh anak dan terdorong baginya untuk berinteraksi dengan bahasa tersebut. ${ }^{6}$

\section{Metode}

Kajian ini merupakan analisis literatur dalam bentuk deskripsi kualitatif. Sajian informasi tentang pemerolehan bahasa dan bakat bahasa. Keduanya memiliki hubungan yang erat dalam proses pembentukan bahasa seorang anak.

\section{Pembahasan}

1. Kontroversiantara Nurture dengan Nature

Proses pemerolehan $\mathrm{B}_{1}$ merupakan suatu hal yang kontroversial di antara para ahli bahasa. Mereka yang menganut aliran behaviorisme mengatakan bahwa pemerolehan bahasa bersifat nurture, yakni pemerolehan itu ditentukan oleh alam

${ }^{6}$ Joseph C. Mukalel, Psychology of Language learning (New Delhi, Discovery Publishing House, 2003), h. 13 
lingkungan. Menurut aliran ini, manusia dilahirkan dengan suatu tabula rasa, yakni semacam piring kosong tanpa apapun. Piring ini kemudian diisi oleh alam sekitar kita, termasuk bahasannya. Jadi Pengetahuan apappun yang kemudian diperoleh oleh manusia semata-mata berasal dari lingkungannya.

Menurut Skinner sebagaimana yang dijelaskan oleh Dardjowidjojo pemerolehan bahasa didasarkan adanya stimulus, kemudian diikuti oleh respon. Bila respon itu benar maka diberi hadiah, bila salah dihukum. Dari proses pengulangan seperti ini akan muncullah kebiasaan. Bahasa, menurut Skinner, tidak lain hanyalah merupakan seperangkat kebiasaan. Kebiasaan hanya bisa diperoleh melalui latihan yang berkelanjutan. Pandangan inilah yang menjadi dasar mengapa latihan drills, merupakan bagian yang sangat penting dalam pembelajaran bahasa asing pada metode seperti Oral Approach atau Audiolingual Approach. ${ }^{7}$

Hal senada juga diungkapkan Mukalel yang mengutip pandangan Skinner bahwa pemerolehan bahasa didasarkan pada pengkondisian operan dan klasik. Skinner mengklasifikasikan perilaku respon operan yang berupa 'mand', tact', atau 'milk', istilah 'tact' merupakan penamaan respon saat anak menamai beberapa objek atau kejadian di lingkungannya dan diperkuat dengan kegembiraan ibunya. Echoic response hanyalah sebuah pengulangan yang ditiru oleh anak berasal dari ucapan orang dewasa, penguatan merupakan stimulasi diri. Respon ini lebih lanjut diperbaiki, dibentuk, dan dimodifikasi oleh ibu dan anggota keluarga lainya melalui ucapan orang dewasa. Pemberian penguatan (rewarding) terhadap kebenaran respon akan membantu anak mengukuhkan dan mengembangkan respon verbal yang akurat. ${ }^{8}$

Di samping mendeskripsikan perkembangan bahasa dari perspektif psikologis dalam hal perilaku, perlu pula untuk mendeskripsikan linguistik dalam hal internalisasi sistem linguistik. Keseluruhan pembelajaran bahasa merupakan proses internalisasi sistem. Pandangan ini secara jelas dan sistematis dikemukakan oleh Noam Chomsky melalui karya-karyanya, yaitu linguistik transformasi generatif. Internalisasi sistem linguistik terjadi di berbagai tingkatan. Seluruh proses pemerolehan bahasa merupakan salah satu internasionalisasi sistem: sistem fonologi, morfologi (kosakata), sistematis, dan semantik bahasa.

Menurut Chomsky sebagaimana dijelaskan oleh Dardjowidjojo, anak memperoleh bahasa seperti dia memperoleh kemampuan untuk berdiri dan berjalan. Hal ini bertentangan dengan pendapat Skinner, yang memandang bahwa pemerolehan bahasa yang didasarkan pada nurture atau teori stimulus-respon. Anak tidak dilahirkan sebagai piring kosong, tabula rasa, tetapi dia telah dibekali dengan sebuah alat yang dinamakan Piranti Pemerolehan Bahasa yang didasarkan pada sifat

7 Skinner dalam Soenjono Dardjowidjojo, Psikolingistik: Pengantar Pemahaman Bahasa Manusia (Jakarta: Yayasan Obor Indonesia, 2005), h. 235

8 Mukalel, Mukalel, Psychology of Language learning (New Delhi, Discovery Publishing House, 2003), h. 17. 
nature. Bahasa bukan suatu kebiasaan tetapi suatu sistem yang diatur oleh seperangkat peraturan (rule-governed). Bahasa juga kreatif dan memiliki ketergantungan pada struktur. Kedua kodrat bahasa ini hanya dimiliki manusia. Karena itu, menyamakan manusia dengan tikus dalam memperoleh pengetahuan(knowledge), khususnya dalam pengetahuan bahasa (knowledge of language) adalah cara yang terlalu menyederhanakan fakta. ${ }^{9}$

Kontroversi antara nature dan nurture ini masih berlanjut meskipun sebagian besar linguis kini percaya bahwa pandangan Chomskylah yang tampaknya mendekati kebenaran. Namun demikian faktor nurture juga tidak dapat dikesampingkan begitu saja. Karya fiksi Edgar Rice Burough, Tarzan, sebenarnya merupakan bukti khayal anak adanya interaksi antara nurture dan nature. Namun, pada tahun 1800 di desa Saint Sermin, daerah Aveyron, Perancis ditemukan anak lelaki berumur 11-12 tahun yang sering menyusup desa dari hutan di sekitarnya untuk mencari makan. Waktu tertangkap dan kemudian dipelihara dan dididik oleh Direktur Institude Orang Tuli, Dr. Sicard, "wild Boy of Aveyron" ini ternyata gagal untuk berbicara seperti manusia pada umumnya. Pelimpahan pendidikan keahli lain, Jean Marc Gaspard Itard, yang kemudian memberi nama Victor kepada anak tersebut, memang mengubah pola laku kehidupannya akan tetapi tetap saja dia tidak dapat berbahasa. Peristiwa yang menggambarkan nurture vs nature juga terdapat pada peristiwa lainnya di California dan Columbus.

Dari gambaran di atas, tampak bahwa baik nature maupun nurture diperlukan untuk pemerolehan bahasa. Nature diperlukan karena tanpa bekal kodrati makhluk tidak mungkin dapat berbahasa. Nurture juga diperlukan karena tanpa adanya input dari alam sekitar bekal yang kodrati itu tidak akan terwujud. ${ }^{10}$

\section{Bakat Bahasa}

Sebagai seorang anak, Hedda menunjukkan bakat untuk seni. Saat ini, Hedda merupakan grafik kesuksesan artis. Bagaimana bakat seperti Hedda berbeda dari kecerdasan umum? Bakat adalah kapasitas kemampuan untuk belajar. ${ }^{11}$ Bakat secara sederhana merujuk pada potensi untuk belajar pengetahuan baru atau kemampuan baru. Skehan menyatakan bahwa, "aptitude is consistently the best predictor of language leraning success." 12Dia tidak setuju dengan argument bahwa upaya menghilangkan peranan bakat dengan menekankan pada sentralitas bakat, yang lebih dipahami sebagai bagian dari cara kerja memori.

${ }^{9}$ Chomsky dalam Soenjono Dardjowidjojo, Psikolingistik: Pengantar Pemahaman Bahasa Manusia (Jakarta: Yayasan Obor Indonesia, 2005), h. 236

10 Dardjowidjojo, Soenjono Dardjowidjojo, Psikolingistik: Pengantar Pemahaman Bahasa Manusia (Jakarta: Yayasan Obor Indonesia, 2005), h. 237

11 Dennis Coon dan John O.Mitterer, Introduction to Psychology Gateways to Mind and Behaiour Eleventh Edition, (United States of America: Thomson Higher Education, 2007), h.364

12 Susan M.Gass dan Larry Selinker, Second Language Acquistion an Introductory Course Thorth Edition, (Uk: Lawrence Erlbaum Association, 2008),h.417-418 
Robinson telah mulai memahami komplek bakat, bahwa rangkaian karakteristik yang menunjukkan pada efisiensi belajar. Bakat dalam pandangan ini merupakan representasi totalitas kemampuan seseorang yang dikelompokkan berdasarkan pada faktor kognitif yang dapat mendukung proses belajar dalam konteks yang berbeda. Ini juga didukung oleh Segalowitz, yang menempatkan bakat kontekstual. Ini bukan membenarkan karakteristik ' tetapi lebih pada refleksi komplek keseluruhan situasi belajar.' ${ }^{13}$

Menurut Michael definisi bakat yaitu "an aptitude may be defined as a person's capacity, or bypothetical potential, for a acquisition of a certain more or less well defined pattern of behavior involved in the performance of a task respect to which the individual has had little or no previous training. Jadi, bakat dari segi kemampuan individu untuk melakukan sesuatu tugas yang sedikit sekali tergnatung kepada latihan mengenai hal tersebut.

Menurut Woodworth dan Marquis, bakat dimasukkan ke dalam kemampuan (ability), di dalam ability memiliki tiga arti, yaitu $:^{14}$

a. Acbievement yang merupakan actual ability, yang dapat diukur langsung dengan alat atau tes tertentu.

b. Capacity yang merupakan potential ability, dapat diukur secara tidak langsung melalui pengukuran kecakapan individu, dimana kecakapan ini berkembang dengan perpaduan antara kemampuan dasar dengan pelatihan yang intensif berdasarkan pengalaman.

c. Aptitude, yaitu kualitas yang hanya dapat diukur dengan tes khusus yang memang diperuntukkan untuk mencakup hal tersebut.

Bakat menurut Chaplin, kemampuan potensial yang dimiliki oleh seseorang untuk mencapai keberhasilan di masa yang akan datang. ${ }^{15}$ Menurut Bingham, kondisi atau sifat-sifat yang dianggap sebagai tanda kemampuan individu untuk menerima latihan, atau seperangkat respon seperti kemampuan berbahasa, musik, dan sebagainya. ${ }^{16}$ Jadi dari definisi di atas, bakat dapat dipahami sebagai kamampuan khusus atau suatu pertanda kemampuan yang sangat menonjol atau lebih mencolok yang terdapat pada diri seseorang, yang secara cepat dapat menyelesaikan, merespon dan menerima latihan-latihan, tugas-tugas, atau hal-hal tertentu. Bila seseorang mengetahui keberbakatannya dalam suatu bidang, maka ia akan terasa lebih mudah dalam memasuki peluangnya dengan kata lain dalam mempelajari dan mengembangkan bakatnya. Dengan kemampuan bakat, tentu seseorang akan mempunyai peluang besar untuk meraih keberhasilan pada masa mendatang.

\footnotetext{
${ }_{13}$ Susan M.Gass dan Larry Selinker, Second Language Acquistion an Introductory Course Thorth Edition, (Uk: Lawrence Erlbaum Association, 2008), h.425

${ }^{14}$ Suryabrata s, Psikologi Pendidikan, (Jakarta: Raja Grafindo Persada, 2004)

${ }^{15}$ Muhibbin Syah, Psikologi Pendidikan, (Bandung: PT. Rosda Karya, 2008), h. 135

${ }_{16}$ H.Sunarto, B.Agung Hartono, Perkembangan Peserta Didik, (Jakarta: Rineka Cipta, 1999), h. 116-117
} 
Bakat merupakan potensi oleh seseorang sebagai bawaan sejak lahir dan bukan sesuatu yang sudah benar-benar nyata dengan jelas. Bakat lebih sebagai kemungkinan yang masih harus diwujudkan.Bakat bermacam-macam dan ada di setiap anak namun berbeda-beda. Salah satunya bakat bahasa. Ada dua jenis bakat bahasa yang dibahas, yaitu bakat bahasa yang berhubungan dengan pemerolehan bahasa pertama (language acquisition) dan bakat bahasa yang berhubungan dengan belajar bahasa kedua atau bahasa asing (language learning).

Hubungan antara bakat dan kesuksesan belajar bahasa kedua menjadi bagian yang penting, jika hanya karena pendapat mengenai bakat dapat mempunyai implikasi sangat besar dalam kehidupan sehari-hari. Jika bakat mengukur penggunaan ukuran kemampuan seseorang dari belajar bahasa asing dan jika mengukur akurasi, kemudian tentunya siswa akan tidak adil dicegah dari pemenerimaan apapun kelebihan yang mungkin akurat dari pengetahuan bahasa lainnya.

Bakat bahasa merujuk pada kemampuan seseorang untuk belajar bahasa lain, tidak ada berbicara bakat bahasa untuk belajar bahasa pertama, terakhir bukan untuk anak tanpa kekurangan kognitif. ${ }^{17}$ Secara tradisional bakat bahasa dipandang sebagai serangkaian variabel kemampuan yang menempatkan beberapa pebelajar untuk belajar materi bahasa baru. Gardner dan McIntyre membagi faktor-faktor perbedaan individu dalam pemerolehan bahasa kedua yang dikategorikan kedalam dua kelas: afektif dan kognitif. Bakat bahasa dipandang sebagai faktor kognitif. Dalam pandangannya dalam penelitian awal bakat, Carroll mendefinisikan bakat sebagai "capability of learning task," yang bergantung pada beberapa kombinasi kurang lebih mengenai karakteristik pebelajar yang tetap. ${ }^{18}$

Dari definisi yang diberikan Carroll dapat digambarkan mengenai hubungan bakat bahasa dengan belajar bahasa kedua. Carroll menamakan hubungan dengan kajian bakat belajar bahasa kedua. Dia merupakan pencipta dari apa yang Skehan sebut "standar 'empat komponen' memandang bakat bahasa" :19

a. Kemampuan pengkodean fonemik, yaitu kemampuan untuk mengidentifikasi bunyi bahasa asing sehingga bunyi-bunyi tersebut dapat diingat. Kemampuan ini juga untuk melihat seperti untuk mampu dan mengkontol hubungan bunyi dengan symbol.

b. Sensitivitas gramatikal, yaitu kemampuan untuk mengenali fungsi gramatikal kata dalam kalimat. Ini tidak mengukur kemampuan untuk nama atau gambaran fungsi, tetapi lebih pada kemampuan untuk melihat apakah kata tidak berbeda

17 M.Gass dan Larry Selinker, Second Language Acquistion an Introductory Course Thorth Edition, (Uk: Lawrence Erlbaum Association, 2008), h.417

${ }^{18}$ Rod Ellis dan Sandra Fotos, Learning a Second Language Through Interaction, (Amsterdam: John Benjamin B.V, 1999), h. 134

${ }_{19}$ M.Gass dan Larry Selinker, Second Language Acquistion an Introductory Course Thorth Edition, (Uk: Lawrence Erlbaum Association, 2008), h.418 
dalam kallimat yang memiliki fungsi sama. Ini muncul secara logis dimana kemampuan ini dapat membantu belajar bahasa lainnya.

c. Kemampuan belajar bahasa induktif, yaitu kemampuan untuk mengidentifikasi pola koresponden dan hubungan antara bentuk dan makna. Kemampuan ini merupakan kemampuan untuk menyimpulkan aturan atau generalisasi bahasa dari contoh bahasa.

d. Kemampuan belajar hapalan, yaitu kemampuan untuk membentuk dan mengingat hubungan antara stimuli. Memori dan pembelajaran. Secara original ini merupakan frase dalam istilah hubungan: kemampuan untuk membuat dan menyebut kembali hubungan antara kata dan frase dalam bahasa aslinya dan bahasa kedua. Ini tidak jelas apakah tipe ini memiliki peranan utama dalam belajar bahasa, tetapi memori untuk materi bahasa jelas penting.

Bakat bahasa asing, menurut Carroll definisikan sebagai "rate at which persons at the secondary school, university and adult level learn to criterion" yang dapat diukur dengan menggunakan tes standar seperti MLAT dan Language Aptitude Battery (LAB). ${ }^{20}$ Konsep bakat bahasa saat ini yang telah Rubin tuliskan dalam penelitian atau karyanya bahwa John Carroll melihat bakat bahasa asing sebagai karakteristik kognitif stabil dari orang-orang yang memiliki bakat untuk belajar bahasa lainnya. Hal ini dirumuskan untuk mengetahui kecepatan seseorang dalam belajar bahasa asing. Untuk mengukur bakat seseorang saat ini menggunakan Modern Language Aptitude Test - MLAT (Carroll dan Sapon) yang telah dirancang pada masa terjadi perang dunia II untuk menyeleksi pebelajar yang memiliki kemampuan terbaik dalam kursus intensif bahasa. Model bakat Carroll terdiri dari empat komponen: kemampuan pengkodean fonetik, hafalan, dan dua komponen lainnya berhubungan dengan kemampuan untuk menganalisis gramatikal (kemampuan belajar gramatikal bahasa). Para ahli telah berusaha untuk membangun kembali konsep bakat agar lebih selaras dengan teori sensitivitas kognitif induktif. ${ }^{21}$

Kemampuan pengkodean fonetik yaitu kemampuan untuk menyimpan bunyi bahasa baru dalam memori. Dua komponen lain dari model bakat Carroll tersebut berhubungan dengan proses pembelajaran. Grammatical sensitivity, the second component, is defined as "the individual's ability to demonstrate his awareness of the syntactical patterning of sentences in a language". Pada komponen ini Carroll menggambarkan dengan jelas bahwa meskipun kinerja (performance) pada komponen ini tidak memerlukan subjek utama untuk mengetahui terminology gramatikal, namun hal ini melibatkan kesadaran akan tata bahasa. Carroll membedakan antara pengetahuan bahasa dengan

20 Stephen D Krashen, Second Language acquisition and Second Language Learning, (Pergamon Press, 1981), h, 19

21 Carol Griffiths. Lesson from Good Language Learners. (Cambridge : Cambridge University Press, 2008). h.142-143 
pengetahuan yang muncul dari alam bawah sadar, hal seperti ini muncul dalam istilah 'kompetensi' Chomsky. ${ }^{22}$

Komponen bakat bahasa ketiga disebut 'kemampuan induktif. Ini merupakan kemampuan untuk 'menguji materi bahasa .... dan dari hal tersebut dapat dicatat dan diidentifikasi pola serta hubungan yang melibatkan makna atau bentuk gramatikal'. Carroll juga berpendapat bahwa bakat bahasa asing memiliki hubungan kedekatan dengan kecerdasan secara umum. Ringkasan Pimsleur mengenai komponen bakat bahasa memiliki kemiripan, tetapi tidak identik dengan model Carroll:23Dengan demikian, dua komponen dari Carroll, kemampuan induktif dan sensitifitas gramatikal, dan satu komponen dari Pimsleur, kecerdasan verbal, berhubungan langsung atau mencerminkan kesadaran dalam belajar bahasa. Bagian lain dari kekuatan bakat, dalam hal ini komponen kedua, berhubungan dengan faktor pendengaran, dan Pimsleur ' komponen motivasi merupakan bagian tambahan dalam membentuk bagian pendengaran.'

Robinson telah merumuskan kembali konsep komponen-komponen bakat bahasa kedalam susunan hirarki kompleksitas bakat yang merupakan kombinasi dari variabel bakat yang telah mempengaruhi kondisi tertentu dalam proses pembelajaran. Susunan elemen-elemen bakat dari robinson, seperti 'bakat untuk fokus pada bentuk' yang memiliki kemampuan untuk 'mencacat kesenjangan' dan 'menyimpan percakapan' yang disampaikan oleh ujaran-ujaran siswa. ${ }^{24}$

Pimsleur mengkonsep 'bakat bahasa untuk belajar bahasa modern' yang memiliki tiga faktor yaitu: ${ }^{25}$

a. Kecerdasan verbal, bahwa, 'pengetahuan terhadap kata-kata dan kemampuan untuk menyusun analitikal dalam penggunaan materi verbal' (p.14)

b. Motivasi, memiliki problematika dengan kompleksitas bakat yang telah disebutkan sebelumnya.

c. Kemampuan audio, yang merupakan 'kemampuan untuk menerima dan memproses informasi melalui telinga' (p.14)

Taksonomi ini merupakan bagian dari fitur-fitur umum konstruksi bakat Carroll: komponen 'kecerdasan verbal' Pimsleur sama dengan 'sensitifitas gramatikal' dan 'kemampuan belajar bahasa induktif', dimana 'kemampuan audio' menghasilkan kesamaan dengan 'kemampuan pengkodean fonetik'. Bagaimanapun ada dua dasar yang membedakan antara kedua konstruksi tersebut. Pertama, dikarenakan PLAB tidak termasuk dalam komponen memori, hal ini secara lengkap berbeda dengan konseptual teori Pimsleur. Kedua, meskipun Carroll mengidentifikasi komponen 'kemampuan belajar induktif', MLAT hanya untuk mengukur kemampuan secara

22 Stephen D Krashen, Second Language acquisition and Second Language Learning, (Pergamon Press, 1981), h. 19-20

23 Ibid., h. 21

${ }^{24}$ Stephen D Krashen, Second Language acquisition and Second Language Learning, (Pergamon Press, 1981), h. 144.

25 Zoltan Dornyei. The Psychology of the Language Learners Individual Differences in Second Language Acquisition. (New Jersey: Lawrence Erlbaum Associates, 2005), h. 40. 
langsung dimana PLAB secara khusus mentargetkan komponen tersebut. Ketiga, Pimsleur melahirkan kemampuan belajar bahasa dalam arti yang lebih luas daripada yang telah dilakukan oleh Carroll dengan memasukkan motivasi sebagai salah satu unsurnya. Untuk membedakan hasil penelitian Carroll dan Pimsleur, Skehan berpendapat bahwa perbedaan tersebut ada antara dua pendekatan yang digunakan "latar belakang yang Carroll gunakan adalah psikologi dan pembelajaran .... dan Pimsleur melibatkan linguistic" (p.29).

Pada tahun 1980-an Skehan melakukan riset lebih lanjut untuk menjelaskan konstruksi bakat Carroll dan sebagai hasilnya berpendapat bahwa untuk menyesuaikan pandangan tentang bakat, hanya ada tiga komponen dari empat komponen yang muncul yaitu : kemampuan audio, kemampuan linguistic, dan kemampuan memori. Kemampuan audio secara esensi sama dengan kemampuan pengkodean fonetik Carroll, dan kemampuan memori berhubungan dengan kemampuan belajar hafalan. Perbedaan utama terletak pada susunan komponen baru, kemampuan linguistik, yang menggambarkan sensitifitas gramatikal Carroll dan kemampuan belajar bahasa induktif.

\section{Bakat Bahasa dan Usia}

Apakah bakat bahasa akan berubah sejalan dengan perkembangan usia baik melalui cara yang positif maupun negative? Jika disisi lain, bakat bahasa adalah karakter, hal itu seharusnya relative stabil. Kecerdasan, contohnya, telah ditemukan menjadi stabil, sebagai buktinya dalam catatan kajian milik Deart dan kawan-kawan. Para ilmuwan mengelola 101 siswa yang berusia 11 tahun di Skotlandia yang telah menjadi bagian dari survey kecerdasan pada tahun 1932. 66 tahun yang lalu mereka melakukan tes yang sama dan hubungan antara skor tes kedua mencapai 0.80 (setelah diujikan dengan statistic korelasi). ${ }^{26}$

Hasil luar biasa menunjukkan bahwa kecerdasan seseorang adalah suatu prediksi kemampuan melalui tes yang sama bahkan beberapa generasi kemudian dan Cooper disebutkan lebih lanjut bahwa bukti pengukuran kecerdasan diukur mulai dari kanak-kanak dengan predictor kecerdasan yang muncul dalam kehidupannya. Dengan kata lain, bagaimanapun bahwa usia merupakan faktor utama dalam kemampuan pembelajaran bahasa seseorang, sebagai buktinya melalui sejumlah literature yang lebih luas pada 'kritikal hipotesis periode' yang menunjukkan hubungan usia dengan perubahan dalam pemerolehan bahasa kedua - dan oleh karena itu, ini bukanlah hal yang tidak masuk akal untuk mengasumsikan beberapa hubungan usia dengan variasi yang digariskan oleh perubahan bakat yang terjadi setiap waktu.

Caroll dan Sapon tidak menemukan bukti-bukti bahwa bakat bahasa dapat berubah setiap waktu dan dua decade kemudian memverifikasi bahwa bakat bahasa

${ }^{26}$ Ibid., h. 44. 
asing muncul pada diri seseorang dalam jangka waktu yang lama. Skehan juga menyimpulkan dari hasil penellitian Bristol bahwa kemampuan belajar bahasa muncul pada usia tiga setengah tahun ( dimana usia tersebut yang digunakan dalam penelitian Bristol untuk mengukur kemampuan bahasa partisipan). Dia juga menunjukkan, bagaimanapun, bahwa hal ini masih belum jelas apakah kemampuan tersebut merupakan bawaan atau dipengaruhi oleh lingkungan awal anak-anak yang mulai dikenal pada usia tiga tahun pertama mereka hidup.

Akhir - akhir ini, Harley dan Hart telah membuktikan bahwa gambaran tersebut tidak begitu jelas. Investigasi di kelas 7 dan 11 yang melibatkan anak-anak sekolah untuk dianalisis bagaimana prediksi kualitas perbedaan komponen bakat dengan perubahan usia. Temuan mereka menunjukkan bahwa berbagai komponen dari bakat yang melibatkan kelompok usia yang berbeda: anak - anak usia muda, memiliki korelasi yang kuat dengan komponen memori, sedangkan pelajar yang usianya lebih tua dalam analisis bahasa memiliki kekuatan yang lebih tinggi. Dalam kajian lebih lanjut, Harley dan Hart menemukan lebih lanjut bukti bahwa bakat alami merupakan hasil hubungan yang dapat memberikan perubahan dengan usia:27Selanjutnya, kita juga dapat memahami catatan dari Grigorenkoet yang berpendapat bahwa bakat bersifat relative tetap yang bergantung bagaimana bakat membangun konsep.

\section{Konsepsi Bakat Bahasa Skehan dan Pemerolehan Bahasa Kedua}

Dalam kesimpulan diskusi kita tentang bakat bahasa, marilah kita pahami bagian penelitian lain, oleh Peter Skehan, bahwa ada potensi untuk mengembangkannya kedepan karena kesamaan teori Robinson hanya kerangka saja, upaya untuk menghubungkan variasi komponen bakat dengan phase berbeda dalam proses pemerolehan bahasa kedua. Pendekatan ini, dapat memandu penggabungan lebih dekat untuk penelitian pemerolehan bahasa kedua dan bakat. Skehan berpendapat bahwa dengan menggunakan pendekatan komponensial untuk menganalisa bakat, kita dapat mengidentifikasi perubahan bakat tertentu dimana relevansi tidak sederhana untuk kelas pembelajaran formal tetapi juga untuk berbagai aspek-aspek umum atau langkah-langkah dalam proses pemerolehan bahasa kedua. Selanjutnya, Skehan menegaskan bahwa bakat menyoroti anggapan kemampuan kognitif alamiah secara umum dan pusat untuk evaluasi relevansi tata bahasa universal terhadap pembelajaran bahasa kedua.

Tabel 1 menunjukkan ajuan Skehan kesesuaian teori antara langkah-langkah pemerolehan bahasa kedua dan komponen bakat. Diduga konstruksi bakat yang ditunjukkan dalam tabel tersebut merupakan hasil kajian Skehan yang berupaya pertama kali untuk menentukan apakah pebelajar akan menunjukkan variasi individu dalam phase proses variase pemerolehan bahasa kedua dan dengan demikian, apakah variasi ini dapat dijelaskan dengan dampak komponen bakat bahasa. Jika jawaban untuk pertanyaan pertama tersebut 'yes' dan untuk pertanyaan kedua 'no', Skehan mengajukan tambahan konstruksi bakat. Skehan mengakui bahwa sistem

${ }^{27}$ Ibid., h. 45. 
yang digambarkan pada tabel 5 merupakan spekulatif, tetapi dia mengklaim, ketegasannya pada langkah ini tidak begitu banyak untuk mengidentifikasi semua komponen pemerolehan bahasa kedua dan bakat dalam cara pemahaman seperti ini dan untuk menetapkan kecermatan mereka dalam mencocokkan sebagai ilsutrasi dari potensial pendekatan ini.

Tabel 1. Ajuan Teori Pengembangan Langkah-langkah Pemerolehan Bahasa Kedua Dengan Bakat Bahasa

\begin{tabular}{|l|l|}
\hline \multicolumn{2}{|l|}{ Skehan's Proposal of SLA Stages and Aptitude Constructs } \\
\hline SLA Stage & Corresponding Aptitude Constructs \\
\hline Input processing strategies, such as segmentation & Attential control working memory \\
\hline Noticing & Phonetic coding ability working memory \\
\hline Pattern identification & $\begin{array}{l}\text { Phonetic coding ability working memory } \\
\text { Grammatical sensitivity } \\
\text { Inductive language learning ability }\end{array}$ \\
\hline Pattern restructuring and manipulation & $\begin{array}{l}\text { Grammatical sensitivy } \\
\text { Inductive language learning ability }\end{array}$ \\
\hline Pattern control & Automatization \\
\hline Pattern integration & Integrative memory \\
\hline & $\begin{array}{l}\text { Chunking } \\
\text { Retrieval memory }\end{array}$ \\
\hline
\end{tabular}

\section{Kesimpulan}

Pemerolehan bahasa ialah proses penguasaan bahasa yang dilakukan oleh anak secara natural pada waktu anak belajar bahasa ibunya (native language). Istilah pemerolehan bahasa dipakai untuk padanan istilah dalam bahasa Inggris yakni acquisition. Pemerolehan bahasa dapatbersifat nurture,yakni pemerolehan itu ditentukan oleh lingkungan. Dalampandangannya, Skinner menyimpulkan bahwa pemerolehan pengetahuan, termasuk pengetahuan pemakaian bahasa didasarkan pada adanya stimulus kemudian diikuti oleh respon.

Chomsky berpandangan bahwa pemerolehan bahasa bukan didasarkan pada nurture tetapi pada nature. Anak memperoleh kemampuan untuk berbahasa seperti dia memperoleh kemampuan untuk berdiri dan berjalan. Anak tidak dilahirkan dengan piring kosong, tetapi dia telah dibekali dengan sebuah alat yang dinamakan Piranti Pemerolehan Bahasa. Baik nature maupun nurture diperlukan untuk pemerolehan bahasa. Nature diperlukan karena tanpa bekal kodrati makhluk 
tidak mungkin dapat berbahasa. Nurture juga diperlukan karena tanpa adanya input dari alam sekitar bekal yang kodrati itu tidak akan terwujud. Sebelum anak dapat mengucapkan kata, dia memakai cara lain untuk berkomunikasi: dia memakai tangis dan gesture (gesture, gerakan tangan, kaki, mata, mulut, dsb). Dengancara-cara seperti ini anak sebenarnya memakai "kalimat" yang protodeklaratif dan protoimperatif.

Dalam tinjauan penellitian yang telah dilakukan, ini menjadi jelas setelah tahun 1970-an dan 1980-an, penelitian bakat bahasa telah menggambarkan dengan lengkap dan saat ini telah menjadi wilayah yang paling disukai dalam penelitian pemerolehan bahasa kedua. Ini adalah bukti kuat bahwa ada beberapa kemampuan kognitif yang memiliki pengaruh terhadap semua aspek dari kesuksesan belajar bahasa kedua, dan penelitian bakat bahasa kontemporer muncul untuk menampilkan psikometrik untuk mengetahui bagaimana dan latar belakang psikolinguistik digunakan untuk mengeksplor kemampuan ini.

Ini juga jelas bahwa wilayah penelitian bakat bahasa merupakan transisi dan kita dapat mengobservasi beberapa tren umum:

1. Penelitian kontemporer tertinggal di belakang tradisi Carroll dan menggambarkan peningkatan psikologi kognitif, psikolinguistik, dan neurolinguistik.

2. Istilah bakat bahasa menjadi semakin dibatasi untuk merujuk pada ukuran gabungan yang diperoleh dari kelebihan bakat, sedangkan para ahli fokus pada kemampuan kognitif khusus, seperti cara kerja memori, yang cenderung menghindari istilah ini.

3. Ada perubahan, sama dengan wilayah kajian lainnya yang menunjukkan penelitian perbedaan individu (misalnya motivasi), untuk memahami bakat bahasa dalam kondisi, menguji pengaruh timbal balik dinamis antara bakat dan konteks.

4. Langkah - langkah kontekstual sensitive dari bakat bahasa membuka kemungkinan baru untuk mengintegrasikan penelitian bakat ke dalam wilayah kajian utama pemerolehan bahasa kedua, dan mereka juga memungkinkan para peneliti untuk menghubungkan kemampuan kognitif yang diinstruksikan dalam praktek pemerolehan bahasa kedua dan praktik di kelas dengan cara yang berguna.

Beberapa petunjuk terhadap penelitian bakat bahasa adalah lebih produktif di masa yang akan datang. Salah satunya telah menjadi pionir oleh Peter Robinson dalam kajian bahasa kedua yang muncul untuk mempelajari pengukuran bakat dalam kombinasi dengan variabel ID dalam variasi kompleksitas, juga menguji interaksi kompleksitas dengan pengajaran dan variabel situasional. Area kedua yang penting adalah untuk mengekplor lebih jauh peranan kerja memori baik dalam pemerolehan bahasa kedua dan bakat bahasa yang kompleks. Saya sependapat dengan Miyake dan Friedman bahwa ' kerja memori sebagai bakat bahasa' yang diajukan sebagai hipotesis, khususnya karena, para ahli menekankan, kerja memori bahasa dapat menangkap esensi semua tiga komponen penting konstruk bakat bahasa yang diusulkan oleh Skehan pada konsepsi dasar Carroll: kapasitas analitik bahasa, kemampuan memori, dan kemampuan koding fonetik.

Namun, kita seharusnya mencatat peringatan Robinson bahwa kapasitas 
kerja memori itu sendiri tidak dapat disejajarkan dengan bakat untuk belajar bahasa: seperti yang dia argumenkan, efektifitas bakat yang komples juga merupakan bagian dari kemampuan kognitif dan oleh karena itu, kepastian proses kerja memori membutuhkan masukan dari variabel ID yang lain dalam konseptual yang akan datang. Area ketiga bahwa mugkin untuk menguji lebih jauh pengaruh kemampuan kognitif yang digabungkan dengan pembelajaran bahasa pertama dalam kapasitas untuk menguasai bahasa kedua, berikut upaya penelitian Sparks, Ganschow, dan asosiasi mereka, yang sebaik dengan Dufva dan Voeten. Akhirnya, garis penyelidikan masa depan yang memiliki potensi yang cukup besar adalah usulan Skehan untuk mencoba dan secara eksplisit menggabungkan komponen bakat tertentu dengan fase proses pemerolehan bahasa kedua.

\section{Daftar Pustaka}

Coon, Dennis dan Mitterer,John O. Introduction to Psychology Gateways to Mind and Behaiour Eleventh Editio. (United States of America: Thomson Higher Education. 2007)

Chomsky, Noam. Lectures on Government and Binding (Dordrecht: Foris, 1981)

Ellis, Rod dan Fotos, Sandra. Learning a Second Language Through Interaction (Amsterdam: Joh Benjamin B.V. 1999)

Dornyei, Zoltan. The Psychology of the Language Learners Individual Differences in Second Language Acquisition (New Jersey: Lawrence Erlbaum Associates. 2005)

Dardjowidjojo, Soenjono. Psikolingistik: Pengantar Pemahaman Bahasa Manusia (Jakarta: Yayasan Obor Indonesia, 2005)

Griffiths, Carol. Lesson from Good Language Learners (Cambridge : Cambridge University Press. 2008)

Gass, Susan M dan Selinker, Larry. Second Language Acquistion an Introductory Course Thorth Edition (Uk: Lawrence Erlbaum Association. 2008)

Krashen, Stephen D. Second Language acquisition and Second Language Learning (Pergamon Press. 1981)

Mukalel, Joseph C. Psychology of Language learning (New Delhi, Discovery Publishing House, 2003)

S. Suryabrata. Psikologi Pendidikan (Jakarta: Raja Grafindo Persada. 2004)

Syah, Muhibbin. Psikologi Pendidikan (Bandung: PT. Rosda Karya. 2008) 
Qawwãm • Volume 13 Nomor 1, Juni 2019

Sunarto, H dan Hartono, B.Agung. Perkembangan Peserta Didik (Jakarta: Rineka Cipta. 1999) 